\title{
TORT LAW TEXT AND MATERIALS BY MARK LUNNEY AND KEN OLIPHANT
}

\author{
Bill Atk in *
}

Mark Lunney and Ken Oliphant, Tort Law Text and Materials Oxford University Press, Oxford, 2000, 819 + lix pages (Reg Retail NZ\$95).

How can there be space in the market for yet another textbook on torts? The answer is that this book is a book of materials and cases, of which there are few in Britain. Hepple \& Matthews and Weir are the leading casebooks, compared with the many more traditional texts such as Winfield, Street, Clerk and Lindsell, Salmond, Fleming, to name only a few. The case method has not been the usually preferred method of teaching in Britain, so the need for casebooks is not that great. The authors of the latest book are from Kings in London and the Cardiff Law School respectively, and both have done research in New Zealand. They obviously felt a need for teaching purposes of a different book and hence have produced the one under review.

The jacket describes the book as "a new generation of tort law textbook". From an international point of view, that may be overstating the case. Nevertheless, this book has some innovative writing and a style which in the end makes it highly commendable. The book would be an excellent one to prescribe for New Zealand students, were it not for the fact that we need more distinctive New Zealand extracts.

From one point of view, preparing a casebook sounds easy. Yet, careful decisions have to be made about what to put in, how to edit it, and what commentary (including tutorial problems) to include. Lunney and Oliphant have done well in this respect. Apart from cases and key statutory provisions, there are highly relevant extracts from a range of authors. This enables readers to enjoy the critiques of conventional writers but also those belonging, for instance, to

* Reader in Law, Victoria University of Wellington. 
feminist and law and economics schools. The frequent pattern of the book is to include such writings after the relevant case law, and then for the authors themselves to provide their own commentary. This commentary is certainly one of the memorable features of the book. It means that the authors have a vehicle to make comparisons with other jurisdictions, to analyse the previous material and to raise critical questions for the reader to mull over. The commentary sections of the book are of high quality and are very well worth delving into in their own right.

It is not so long ago that New Zealand tended to look to Britain for its precedents, especially in relation to common law topics. This is now far less true, as Canadian and Australian jurisprudence in particular are used as sources of authority. The Privy Council in cases such as Invercargill City Council $v$ Hamlin $^{1}$ and Lange $v$ Atkinson ${ }^{2}$ has countenanced the seamless thread of the common law being easily broken to meet local biases. This is not to say that British judgments are not still the subject of close scrutiny in this part of the world, but the foundations upon which British law is built are beginning to be re-laid. One of the stand-out features of Lunney and Oliphant is the impact that European law and its domestic companion piece, the Human Rights Act 1998, are having on the development of the law. The operation of the Human Rights Act has been influencing judges for a while. For example, the leading libel case, Reynolds $v$ Times Newspapers, ${ }^{3}$ took freedom of expression as its starting point and the House of Lords had earlier anticipated human rights arguments in Derbyshire County Council v Times Newspapers. ${ }^{4}$ Several headings in Lunney and Oliphant reinforce the altered groundrules: "Tort Law in the Human Rights Era", "Negligence in the Human Rights Era", and "Euro-Torts" (the latter being analogous to the tort of breach of statutory duty and based on "a developing principle of liability in damages for the violation of Community rights"). ${ }^{5}$

In England, there is no separate tort of breach of privacy as there now is in New Zealand. Gordon Kaye, the lead actor in Allo! Allo!, managed to obtain an injunction against some intrusive journalism by slotting himself with in the laws of libel and malicious falsehood but a tort of invasion of privacy would have been much neater. ${ }^{6}$ Lunney and Oliphant believe that

1 Invercargill City Council v Hamlin [1996] 1 NZLR 513 (PC).

2 Lange v Atkinson [2000] 1 NZLR 257 (PC).

3 Reynolds $v$ Times Newspapers [1999] 3 WLR 1010 (HL).

4 Derbyshire County Council v Times Newspapers [1993] AC 534 (HL).

5 Lunney \& Oliphant Tort Law Text and Materials (Oxford University Press, Oxford, 2000) 523.

$6 \quad$ Kaye v Robertson [1991] FSR 62 (CA). 
"[i]t now appears that the passage of the Human Rights Act will give renewed impetus to efforts to strengthen the protection of privacy in English law." They quote the Lord Chancellor, Lord Irvine, as saying that the judiciary is "pen-poised to develop a right of privacy".?

Perhaps it is the law of negligence which faces the greatest changes. The pivotal turning point is the decision of the European Court of Human Rights in Osman v United Kingdom ${ }^{8}$ in which the striking out of a claim against the police for its handling of various incidents leading to homicide was held to breach the applicants' right of access to a court in violation of the European Convention on Human Rights. According to Lunney and Oliphant: ${ }^{9}$

The effects of the Osman decision remain difficult to predict, but they may potentially have a radical impact on two basic features of English law. First, in term of procedure, even a narrow interpretation of the decision would limit (perhaps even exclude entirely) recourse to the strikingout procedure in actions for negligence - at least in cases where the issue is the fairness, justice and reasonableness of recognising a duty. Secondly, as a matter of substantive law, the decision seems to cast doubt upon the English courts' basic approach to the tort of negligence whereby questions of policy of a general nature are considered separately from an individualised consideration of the justice of the claimant's case, and may be held to outweigh all conceivable arguments made on behalf of an individual claimant.

One of the areas where these points will be felt the most is that of liability of public bodies. Osman itself attacks immunities in favour of the police. A further decision of the European Commission of Human Rights has already undermined the immunity given social workers in $X v$ Bedfordshire, ${ }^{10}$ yet Lunney and Oliphant are critical of the later House of Lords judgment (in rather different circumstances) in Barrett $v$ London Borough of Enfield ${ }^{11}$ allowing potential liability. The judicial approach in Barrett

marks the degeneration of law into a collection of single instances, with opinion usurping the role of principle, and coherence consigned to the scrap-heap. As the courts seem content to re-assess the

7 Lunney \& Oliphant, above n 5, 667.

8 Osman v United Kingdom [1999] 1 FLR 193 (ECHR).

9 Lunney \& Oliphant, above n 5, 127-8.

$10 X v$ Bedfordshire [1995] 2 AC 63 (HL). See $Z v U K$ [2000] 2 FCR 245 (E Comm HR).

11 Barrett v London Borough of Enfield [1999] 3 WLR 79 (HL). The quote is from Lunney \& Oliphant, above n 5,443 . 
policy question afresh in each new case, it becomes well nigh impossible to predict which way individual cases will go, or indeed to identify any rational basis for reconciling divergent outcomes in past cases. All of which attests to an utter dereliction of judicial responsibility in this area.

According to Lunney and Oliphant, the human rights era may not only remove immunities from public bodies but also cast positive duties on them, producing a significant increase in their potential liabilities. Would Stovin $v$ Wise ${ }^{12}$ (no liability on a local council for failing to make safe a dangerous intersection despite an earlier decision to do so) be decided differently in the human rights era? Will the general reluctance of the common law to allow liability for omissions be similarly affected? Lunney and Oliphant rightly leave these enticing questions open.

How will all this affect New Zealand tort law? Obviously New Zealand is not bound by European law, and its own Human Rights Act is rather weaker than the British one. Indeed, tort law in New Zealand has been less affected by its own human rights rules than English law may be. Yet, like other Commonwealth countries, New Zealand has already broken the shackles of conservative judicial tendencies in Britain. Ironically, if Lunney and Oliphant are correct, it may be Britain which becomes the more expansive and innovative. May we predict that whatever happens will filter through to New Zealand in some guise or another?

Lunney and Oliphant have produced a very valuable book, well worth New Zealand lawyers dipping into. Despite its length and rather small typeface, it should rank very highly in years to come.

12 Stovin v Wise [1996] AC $923(\mathrm{HL})$. 